\title{
Tanggap Pertumbuhan dan Hasil Tiga Varietas Kacang Hijau terhadap Lama Genangan
}

\section{Growth and Yield Responses of Three Mungbean Varieties to Waterlogging Duration}

\author{
Sri Ayu Dwi Lestari*, Andy Wijanarko, dan Henny Kuntyastuti \\ ${ }^{1}$ Balai Penelitian Tanaman Aneka Kacang dan Umbi \\ JL. Raya Kendalpayak Km 8 Kotak Pos 66 Malang 65101, Indonesia
}

Diterima 11 September 2017/Disetujui 22 November 2018

\begin{abstract}
The objective of this research was to determine growth and yield responses of three mungbean varieties to waterlogging duration. The experiment was conducted at a screenhouse of ILETRI, Malang, East Java, from October to December 2016 using Alfisol soil from Probolinggo, East Java. The experiment consisted of two factors that were laid out in a factorial randomized complete block design with three replications. The first factor was mungbean varieties, namely Sriti, Vima 1, and Vima 2. The second factor was waterlogging durations, namely 0, 2, 4, and 6 days. The waterlogging treatments started at 20 days after planting. Mungbean plants fertilized with $250 \mathrm{~kg}$ Phonska hat at the time of planting. The results showed that waterlogging treatments had negative effects on growth of the three varieties, indicated by a reduction in stem dry weight and leaf dry weight of the plants. Sriti variety was tolerant to waterlogging, Vima 1 was moderate tolerant, and Vima 2 was sensitive.
\end{abstract}

Keywords: Alfisol soil, Vigna radiata, waterlogging stress

ABSTRAK

Penelitian ini bertujuan untuk mengetahui pengaruh lama genangan terhadap pertumbuhan dan hasil tiga varietas tanaman kacang hijau. Penelitian dilaksanakan di rumah kasa Balitkabi, Malang, Jawa Timur pada Oktober-Desember 2016 menggunakan tanah Alfisol dari Probolinggo, Jawa Timur. Percobaan terdiri atas dua faktor yang disusun dalam rancangan acak kelompok (RAK) faktorial dengan tiga ulangan. Faktor pertama adalah varietas kacang hijau, yaitu Sriti, Vima 1, dan Vima 2. Faktor kedua adalah lama genangan, yaitu: 0, 2, 4, dan 6 hari. Perlakuan genangan dimulai pada umur 20 HST. Kacang hijau dipupuk $250 \mathrm{~kg}$ Phonska ha-1 yang diberikan pada saat tanam. Hasil penelitian menunjukkan bahwa perlakuan genangan berpengaruh negatif terhadap pertumbuhan ketiga varietas, ditunjukkan dengan pengurangan bobot kering batang dan bobot kering daun tanaman. Varietas Sriti tergolong toleran terhadap genangan, Vima 1 agak toleran, dan Vima 2 tidak toleran.

Kata kunci: cekaman genangan, tanah Alfisol, Vigna radiata

\section{PENDAHULUAN}

Pemanasan global memberikan dampak terhadap perubahan iklim, antara lain perubahan pola dan intensitas curah hujan yang dapat menyebabkan kekeringan atau banjir. Kondisi ini dapat mempengaruhi pertumbuhan dan perkembangan tanaman. Tanaman pangan merupakan tanaman semusim yang tergolong peka terhadap perubahan pola dan intensitas curah hujan atau kelebihan dan kekurangan air. Hal ini dapat menurunkan produktivitas dan kualitas hasil. Upaya mengantisipasi dampak perubahan iklim dapat dilakukan dengan dukungan teknologi yang

\footnotetext{
* Penulis untuk korespondensi. e-mail: estawinasa@gmail.com
}

inovatif dan adaptif. Pengembangan produk pertanian yang toleran terhadap variabilitas dan perubahan iklim merupakan salah satu upaya adaptasi yang dapat dilakukan (Balitbangtan, 2011).

Kacang hijau merupakan salah satu komoditas pertanian penting di Indonesia, baik sebagai bahan pangan maupun industri pangan, sehingga dapat dijadikan alternatif bahan makanan. Sentra produksi kacang hijau di Indonesia tersebar di Jawa Tengah, Jawa Timur, Nusa Tenggara Barat, Sulawesi Selatan, Jawa Barat, dan Nusa Tenggara Timur (Trustinah et al., 2014). Produksi dan kualitas hasil kacang hijau berpotensi menurun dengan adanya perubahan iklim yang belakangan semakin marak terjadi. Salah satu gejala perubahan iklim yang mempengaruhi produksi dan kualitas hasil kacang hijau yaitu curah hujan tinggi 
yang menyebabkan adanya kelebihan air atau tergenang. Berdasarkan hasil penelitian Singh dan Singh (2011), kacang hijau tidak dapat bertahan jika tergenang, terutama selama fase awal pertumbuhan yang merupakan periode kritisnya.

Daerah sentra produksi kacang hijau di Indonesia yang berpeluang mengalami cekaman kelebihan air (tergenang) adalah di Jawa Barat, Jawa Tengah, dan Jawa Timur. Salah satu komponen teknologi yang berpeluang meningkatkan produktivitas kacang hijau pada kondisi tergenang adalah varietas unggul toleran genangan. Kementerian Pertanian Republik Indonesia telah melepas sebanyak 24 varietas unggul sejak tahun 1945 hingga 2016 (Balitkabi, 2016), namun belum tersedia varietas yang dilepas khusus untuk toleran genangan. Oleh karena itu, perlu evaluasi toleransi varietas-varietas kacang hijau yang sudah dilepas, terhadap cekaman genangan.

Berdasarkan hasil dari beberapa penelitian, cekaman genangan dapat memundurkan waktu berbunga pada tanaman kacang hijau (Kumar et al., 2013); menyebabkan penurunan luas daun, bobot basah, dan kering tanaman; serta panjang akar tanaman kedelai pada konsentrasi genangan 200\% (Rohmah dan Saputro, 2016); menyebabkan kerusakan akar, peningkatan kandungan etilen, penurunan kandungan klorofil daun, dan $\mathrm{N}$ jaringan pada tanaman cabai merah (Susilawati et al., 2012). Tanaman yang mampu tumbuh pada kondisi tergenang (toleran genangan) akan membentuk ruang aerenkim pada korteks akar dan batang, fotosintesis tetap tinggi, kandungan klorofil rendah yang menyebabkan absorbsi cahaya rendah sehingga tidak terjadi kerusakan sistem fotosintesis oleh fotooksidasi, serta struktur daun dan epidermis tidak rusak sehingga dapat menghindari kekurangan oksigen (Colmer dan Voesenek, 2009; Du et al., 2012; Somavilla dan Riberio, 2012). Perlakuan lama genangan 12, 24, 36, dan 48 jam setelah tanam dapat menurunkan hasil kacang hijau masingmasing sebesar 12.47, 27.17, 46, dan 74.36\% (Ullah, 2006). Berkaitan dengan toleransi kacang hijau terhadap genangan, maka dilakukan penelitian dengan tujuan untuk mengetahui pengaruh lama genangan terhadap pertumbuhan dan hasil tiga varietas kacang hijau.

\section{BAHAN DAN METODE}

Percobaan dilaksanakan di rumah kasa Balai Penelitian Tanaman Aneka Kacang dan Umbi (Balitkabi), Malang, Jawa Timur pada bulan Oktober-Desember 2016. Percobaan menggunakan tanah Alfisol yang diambil dari Kebun Percobaan Muneng, Kabupaten Probolinggo pada kedalaman 0-20 cm. Percobaan terdiri atas dua faktor yang disusun dalam rancangan acak kelompok (RAK) faktorial dengan tiga ulangan. Faktor pertama adalah tiga varietas kacang hijau, yaitu: Sriti, Vima 1, dan Vima 2. Alasan pemilihan ketiga varietas kacang hijau tersebut adalah karena sudah banyak berkembang di masyarakat. Faktor kedua adalah lama genangan, yaitu: tanpa tergenang, tergenang dua hari, empat hari, dan enam hari pada fase vegetatif dimulai umur 20 hari setelah tanam (HST). Sebelum perlakuan genangan, polibag tidak dimasukkan ke dalam ember. Saat perlakuan penggenangan, polibag berukuran $12 \mathrm{~cm}$ x 17 $\mathrm{cm}$ berisi $8 \mathrm{~kg}$ tanah (tinggi $14 \mathrm{~cm}$ ) dimasukkan ke dalam ember berukuran 12 L (tinggi $24 \mathrm{~cm}$ ), sehingga ketika diberi genangan, air yang keluar dari lubang-lubang polibag tetap terjaga di dalam ember. Ketinggian air tetap dijaga setinggi $10 \mathrm{~cm}$ dari permukaan tanah sesuai lamanya perlakuan. Saat perlakuan genangan selesai, polibag kembali dikeluarkan dari dalam ember sehingga air dapat keluar melalui lubanglubang polibag. Sebelum dan sesudah perlakuan genangan, dilakukan penyiraman sebanyak 2 kali dalam seminggu (volume penyiraman air $1 \mathrm{~L}$ tiap polibag). Penyiraman dilakukan mulai dari tanam hingga panen, kecuali saat perlakuan genangan umur 20-26 HST.

Setiap unit perlakuan ditanam sebanyak 6 polibag per ulangan, masing-masing polibag berisi $8 \mathrm{~kg}$ tanah yang telah dikeringanginkan. Tiga polibag untuk pengamatan destruktif yang dilaksanakan pada dua minggu setelah perlakuan genangan selesai dan tiga polibag untuk pengamatan non destruktif. Tanaman dipupuk Phonska (15\% N, 15\% $\mathrm{P}_{2} \mathrm{O}_{5}$, $15 \% \mathrm{~K}_{2} \mathrm{O}$ ) dengan takaran $250 \mathrm{~kg} \mathrm{ha}^{-1}$ yang dilakukan pada saat tanam (setara dengan $1.5 \mathrm{~g}$ per polibag).

Kacang hijau ditanam tiga benih per polibag. Penjarangan dilakukan pada umur 7 HST dengan menyisakan satu tanaman per polibag. Penyiangan dilakukan secara manual pada umur 20 HST hingga panen, dengan interval 10 hari. Pengendalian hama belalang dilakukan dengan pemberian pestisida berbahan aktif deltametrin, pengendalian kutu kebul dengan pemberian pestisida berbahan aktif monosultap, dan untuk mengendalikan penyakit yang disebabkan oleh jamur dilakukan dengan pemberian fungisida berbahan aktif kaptan.

Peubah pertumbuhan non destruktif yang diamati pada tiga ulangan yaitu: (1) tinggi tanaman (cm) dilakukan mulai umur 10 HST hingga panen, dengan interval 10 hari; (2) umur berbunga; dan (3) indeks klorofil daun yang diukur dengan Chlorophylmeter SPAD-502 dilakukan mulai umur 10 HST hingga 50 HST, dengan interval 10 hari. Pengamatan komponen hasil saat panen terdiri atas jumlah polong isi, jumlah biji, dan bobot kering biji per tanaman.

Pengamatan destruktif terdiri atas peubah volume akar, luas daun, bobot kering akar, bobot kering batang, dan bobot kering daun yang dilakukan dua minggu setelah masing-masing perlakuan lama genangan selesai. Volume akar diamati dengan memasukkan akar ke dalam gelas ukur yang sudah berisi $100 \mathrm{~mL}$ air, selisih antara volume air sebelum dan setelah akar dimasukkan adalah volume akar (Munarso, 2011). Luas daun diukur dengan metode gravimetri. Daun dikeringkan menggunakan oven pada suhu $60{ }^{\circ} \mathrm{C}$ selama 48 jam, setelah itu ditimbang bobot kering daunnya. Sebagai standar, satu helai daun dipotong dengan ukuran $2 \mathrm{~cm} \times 2 \mathrm{~cm}$ yang diambil dari bagian tengah daun, daun tersebut dikeringkan menggunakan oven pada suhu 60 ${ }^{\circ} \mathrm{C}$ selama 48 jam, setelah itu ditimbang bobot keringnya. Luas daun didapat dari perkalian luas standar $\left(4 \mathrm{~cm}^{2}\right)$ dengan bobot kering daun total dibagi dengan bobot kering daun standar. Data dianalisis menggunakan sidik ragam dan ketika terdapat pengaruh yang berbeda nyata dilakukan uji beda nyata terkecil (BNT) pada taraf $\alpha=5 \%$. 


\section{HASIL DAN PEMBAHASAN}

\section{Pertumbuhan Tanaman}

Umur 50\% berbunga mengalami penundaan pada semua varietas kacang hijau yang diuji. Umur 50\% berbunga varietas Sriti pada 36 HST, varietas Vima 1 dan Vima 2 pada umur 35 dan 41 HST. Berdasarkan deskripsi varietas (Balitkabi, 2016), umur 50\% berbunga untuk varietas Sriti, Vima 1, dan Vima 2 masing-masing adalah 35, 33, dan 33 HST. Penundaan waktu berbunga tersebut serupa dengan hasil penelitian Kumar et al. (2013) pada tanaman kacang hijau yang diberikan penggenangan selama 3, 6, dan 9 hari saat umur 30 HST.

Pola pertumbuhan tiga varietas kacang hijau hampir sama, yaitu umur 10 HST hingga 30 HST merupakan pertumbuhan lambat, antara umur 30 hingga 50 HST lebih cepat, dan relatif tetap setelah umur 50 HST. Sejak umur 10 HST hingga panen, varietas Vima 2 tumbuh lebih tinggi dibandingkan dengan varietas Sriti maupun Vima 1, kecuali pada umur 40 HST (Gambar 1). Hal tersebut sejalan dengan deskripsi varietas unggul kacang hijau bahwa varietas Vima 2 memiliki tinggi maksimal $64.3 \mathrm{~cm}$, Vima $153 \mathrm{~cm}$, dan Sriti 40-60 cm (Balitkabi, 2016).

Lama genangan mempengaruhi tinggi tanaman umur 30 dan 40 HST. Hal ini menunjukkan bahwa pengaruh perlakuan lama genangan hanya terjadi umur 30 dan 40 HST. Lama genangan 2-6 hari sejak umur 20-26 HST menghambat pertumbuhan kacang hijau, sehingga tanaman pada perlakuan kontrol saat umur 30 dan 40 HST lebih tinggi dibandingkan dengan tanaman yang diberi perlakuan genangan. Semakin lama waktu genangan, maka semakin lambat pertumbuhan kacang hijau (Gambar 2). Hal ini juga didukung oleh pernyataan Amin et al. (2017) bahwa tinggi tanaman pada perlakuan genangan 6 hari mengalami penurunan dibandingkan pada perlakuan kontrol, genangan 2 hari, maupun 4 hari pada 10 genotipe kacang hijau.

Setelah umur $40 \mathrm{HST}$, pertumbuhan tanaman yang diberi perlakuan lama genangan 2 dan 4 hari kembali normal, ditandai dengan tinggi tanaman yang setara dengan tinggi tanaman pada perlakuan kontrol, sedangkan pada perlakuan lama genangan 6 hari pertumbuhan tanaman tidak bisa kembali normal, ditandai dengan tinggi tanaman

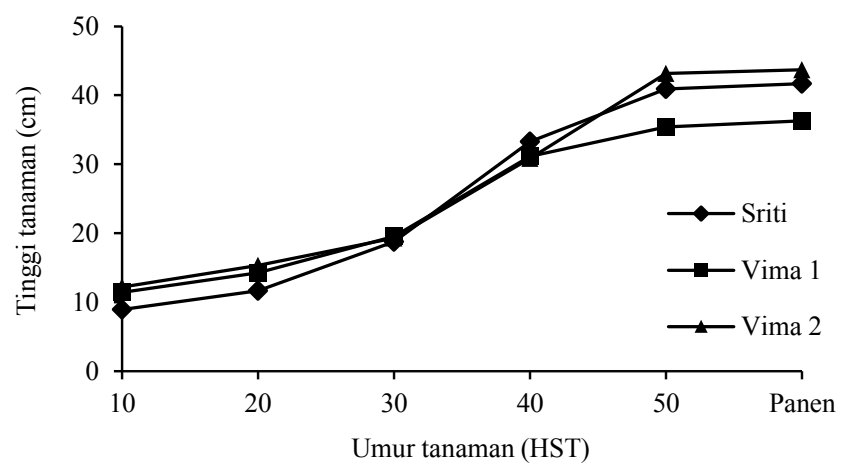

Gambar 1. Tinggi tanaman kacang hijau varietas Sriti, Vima 1, dan Vima 2 selama fase pertumbuhan yang tetap lebih rendah dari perlakuan yang lainnya. Berdasarkan hasil penelitian Insausti et al. (2001) pada tanaman Paspalum dilatatum dan Striker et al. (2005) pada tanaman Lotus cornciculatus L. dan Lotus glaber Mill., hal tersebut disebabkan oleh adanya periode pemulihan ("recovery") pada tanaman yang diberi perlakuan genangan, sehingga tinggi tanaman dapat setara dengan tinggi tanaman pada perlakuan kontrol (tanpa cekaman genangan). Hal ini diduga sebagai mekanisme adaptif dari tanaman yang terkena cekaman genangan. Mekanisme adaptif tanaman yang mampu bertahan dari kondisi cekaman genangan biasanya ditunjukkan dengan peningkatan ketersediaan formasi aerenkim, memiliki aktivitas jalur glikolitik, dan enzim fermentasi yang lebih besar pada tanaman gandum (Alamgir dan Uddin, 2011). Tanaman aneka kacang yang dapat bertahan dari kondisi cekaman genangan memiliki mekanisme seperti peningkatan ketersediaan formasi aerenkim, aktivitas glikolisis, dan enzim fermentasi yang lebih besar, serta adanya pembentukan akar adventif untuk mengatasi stress oksidatif yang disebabkan oleh penggenangan air (Mimi, 2015).

Hasil analisis ragam menunjukkan bahwa interaksi antara lama genangan dan varietas kacang hijau berpengaruh terhadap bobot kering akar dan bobot kering daun. Volume akar dan luas daun dipengaruhi oleh perbedaan varietas (Tabel 1). Varietas Sriti memperoleh volume akar dan luas daun tertinggi dibandingkan dengan varietas lainnya. Tingginya nilai volume akar pada varietas Sriti kemungkinan berasal dari banyaknya akar adventif yang terbentuk akibat cekaman genangan. Banyaknya akar adventif yang terbentuk dapat membantu tanaman dan unsur-unsur yang berperan dalam memproduksi daun yang lebih banyak sehingga luas daun menjadi lebih tinggi.

Interaksi antara varietas kacang hijau dengan lama genangan mempengaruhi bobot kering akar dan bobot kering daun. Bobot kering akar per tanaman tertinggi diperoleh varietas Sriti dengan perlakuan lama genangan 6 hari (Tabel 2). Peningkatan rata-rata bobot kering akar per tanaman yang lebih tinggi pada varietas Sriti menunjukkan daya adaptasi yang lebih tinggi terhadap genangan selama 6 hari melalui pembentukan akar adventif yang lebih banyak. Penelitian ini menunjukkan bahwa varietas Sriti memiliki bobot kering akar yang lebih tinggi dibandingkan varietas lainnya,

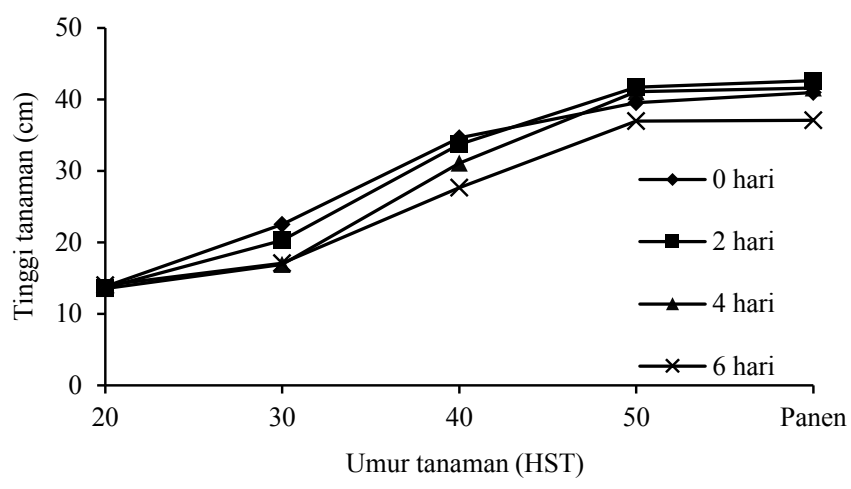

Gambar 2. Tinggi tanaman kacang hijau pada perlakuan lama genangan selama fase pertumbuhan 
Tabel 1. Volume akar, luas daun, bobot kering akar, bobot kering batang, dan bobot kering daun kacang hijau pada saat destruktif

\begin{tabular}{|c|c|c|c|c|c|}
\hline Perlakuan & $\begin{array}{l}\text { Volume akar per } \\
\text { tanaman } \\
(\mathrm{mL})\end{array}$ & $\begin{array}{l}\text { Luas daun per } \\
\text { tanaman } \\
\left(\mathrm{cm}^{2}\right)\end{array}$ & $\begin{array}{l}\text { Bobot kering akar } \\
\text { per tanaman } \\
(\mathrm{g})\end{array}$ & $\begin{array}{l}\text { Bobot kering } \\
\text { batang per } \\
\text { tanaman }(\mathrm{g})\end{array}$ & $\begin{array}{l}\text { Bobot kering daun } \\
\text { per tanaman } \\
(\mathrm{g})\end{array}$ \\
\hline \multicolumn{6}{|l|}{ Varietas } \\
\hline Sriti & $1.6 \mathrm{a}$ & $110.8 \mathrm{a}$ & $0.7 \mathrm{a}$ & $1.9 \mathrm{a}$ & $1.9 \mathrm{a}$ \\
\hline Vima 1 & $1.3 \mathrm{~b}$ & $83.2 \mathrm{~b}$ & $0.4 \mathrm{~b}$ & $1.7 \mathrm{a}$ & $1.6 \mathrm{a}$ \\
\hline Vima 2 & $1.2 \mathrm{~b}$ & $82.8 b$ & $0.4 b$ & $1.6 \mathrm{a}$ & $1.6 \mathrm{a}$ \\
\hline \multicolumn{6}{|c|}{ Lama genangan } \\
\hline 0 hari & $1.4 \mathrm{a}$ & $114.2 \mathrm{a}$ & $0.6 \mathrm{a}$ & $2.5 \mathrm{a}$ & $2.3 \mathrm{a}$ \\
\hline 2 hari & $1.5 \mathrm{a}$ & $77.6 \mathrm{a}$ & $0.4 \mathrm{~b}$ & $2.0 \mathrm{a}$ & $1.6 \mathrm{~b}$ \\
\hline 4 hari & $1.3 \mathrm{a}$ & $88.4 \mathrm{a}$ & $0.4 \mathrm{~b}$ & $1.3 b$ & $1.5 b$ \\
\hline 6 hari & $1.4 \mathrm{a}$ & $88.8 \mathrm{a}$ & $0.6 \mathrm{a}$ & $1.4 \mathrm{~b}$ & $1.5 \mathrm{~b}$ \\
\hline Rata-rata & 1.4 & 92.3 & 0.5 & 1.8 & 1.7 \\
\hline Interaksi & tn & tn & $*$ & tn & $*$ \\
\hline
\end{tabular}

Keterangan: Angka yang diikuti oleh huruf yang berbeda pada kolom yang sama untuk faktor perlakuan yang sama menunjukkan perbedaan yang nyata menurut uji BNT pada $\alpha=5 \%$

sehingga dapat dikategorikan varietas tersebut toleran terhadap genangan selama 6 hari. Genotipe kacang hijau yang toleran genangan akan memiliki akar adventif yang lebih banyak sebagai mekanisme untuk mempertahankan diri dari cekaman genangan, hal tersebut dapat dilihat dari bobot kering akar yang lebih tinggi (Islam et al., 2010). Perlakuan genangan juga mempengaruhi pertumbuhan akar. Secara umum, akar tanaman kacang hijau akan rusak setelah terkena banjir, lalu tanaman akan memproduksi akar adventif dalam waktu 48 jam (2 hari) setelah tergenang.
Setelah akar aslinya rusak bahkan sampai mati, tanaman akan menyesuaikan diri terhadap situasi genangan dengan mempercepat tumbuhnya akar adventif baru pada tanaman kacang hijau (Islam et al., 2007) dan pada tanaman kacang faba [Vicia faba L. minor] (Pociecha et al., 2008).

Bobot kering daun per tanaman tertinggi didapatkan pada interaksi antara varietas Vima 2 dengan perlakuan tanpa genangan dan terendah pada varietas Vima 2 dengan lama genangan 2 hari (Tabel 2). Penurunan akumulasi bahan kering pada tanaman yang tergenang dan periode pemulihan

Tabel 2. Pengaruh interaksi antara lama genangan dengan varietas terhadap bobot kering akar dan bobot kering daun kacang hijau

\begin{tabular}{|c|c|c|c|c|c|}
\hline \multirow{2}{*}{ Varietas } & \multicolumn{4}{|c|}{ Lama genangan (hari) } & \multirow{2}{*}{ Rata-rata } \\
\hline & 0 & 2 & 4 & 6 & \\
\hline \multicolumn{6}{|c|}{ Bobot kering akar per tanaman $(\mathrm{g})$} \\
\hline Sriti & $0.7 \mathrm{ab}$ & $0.4 \mathrm{cde}(43)^{1)}$ & $0.6 \mathrm{ab}(14)$ & $0.8 \mathrm{a}(-14)$ & $0.6 \mathrm{~A}$ \\
\hline Vima 1 & $0.6 \mathrm{abc}$ & $0.5 \mathrm{cde}(17)$ & $0.2 f(67)$ & $0.6 \mathrm{bcd}(0)$ & $0.4 \mathrm{~B}$ \\
\hline Vima 2 & $0.6 \mathrm{abc}$ & $0.3 \mathrm{ef}(50)$ & $0.2 f(67)$ & $0.4 \operatorname{def}(33)$ & $0.4 \mathrm{~B}$ \\
\hline Rata-rata & $0.64 \mathrm{~A}$ & $0.38 \mathrm{~B}$ & $0.35 \mathrm{~B}$ & $0.57 \mathrm{~A}$ & \\
\hline $\mathrm{KK}(\%)$ & 1.86 & & & & \\
\hline \multicolumn{6}{|c|}{ Bobot kering daun per tanaman $(\mathrm{g})$} \\
\hline Sriti & $2.0 \mathrm{ab}$ & $1.7 \mathrm{bcde}(15)$ & $2.1 \mathrm{ab}(-5)$ & $1.9 \mathrm{bcd}(5)$ & $1.9 \mathrm{~A}$ \\
\hline Vima 1 & $2.0 \mathrm{abc}$ & $2.0 \mathrm{bc}(0)$ & $1.2 \mathrm{de}(40)$ & 1.3 bcde $(35)$ & $1.6 \mathrm{~A}$ \\
\hline Vima 2 & $2.7 \mathrm{a}$ & $1.0 \mathrm{e}(63)$ & $1.3 \mathrm{cde}(52)$ & $1.4 \mathrm{bcde}(48)$ & $1.6 \mathrm{~A}$ \\
\hline Rata-rata & $2.5 \mathrm{~A}$ & $1.6 \mathrm{~B}$ & $1.5 \mathrm{~B}$ & $1.5 \mathrm{~B}$ & \\
\hline KK $(\%)$ & 5.03 & & & & \\
\hline
\end{tabular}

Keterangan: Angka yang diikuti oleh huruf yang berbeda pada masing-masing peubah menunjukkan perbedaan yang nyata menurut uji BNT pada $\alpha=5 \% ;{ }^{1)}$ Angka dalam tanda kurung merupakan persentase penurunan terhadap kontrol (tanpa genangan), dilihat secara horizontal per varietas 
setelah perlakuan selesai, merupakan fenomena umum yang terjadi pada tanaman kacang hijau (Islam et al., 2014).

\section{Indeks Klorofil Daun (IKD)}

Nilai IKD tiga varietas kacang hijau pada umur 10, 20, 40, dan 50 HST hampir sama. Nilai IKD varietas Vima 2 pada umur 30 HST menunjukkan nilai tertinggi, yaitu 39.8 SPAD (Soil Plant Analysis Development). Nilai IKD varietas Sriti menurun dari 36.8 SPAD pada umur 20 HST menjadi 35.2 SPAD pada umur 30 HST atau setelah perlakuan genangan 2-6 hari. Pada 30 HST tersebut, IKD daun varietas Vima 2 lebih tinggi daripada varietas Sriti dan Vima 1 yang mengindikasikan kandungan klorofil lebih tinggi. Nilai IKD ketiga varietas kacang hijau pada umur 30 HST ke umur 40 HST meningkat pesat, karena cekaman genangan sudah terlampaui dan tanaman kacang hijau sudah mengalami pemulihan (Gambar 3). Kandungan klorofil pada varietas tanaman yang toleran cekaman genangan lebih tinggi karena pertumbuhan tanaman lebih baik dan unsur-unsur yang berperan sebagai penyusun klorofil lebih banyak (Safrizal et al., 2008).

Perlakuan lama genangan nyata berpengaruh terhadap IKD pada umur $30 \mathrm{HST}$ dan $40 \mathrm{HST}$. Indeks klorofil daun pada umur 20 HST relatif sama karena belum diberi perlakuan, rata-rata 36.2 SPAD. Genangan selama empat dan enam hari mulai umur 20 HST menurunkan IKD kacang hijau pada umur 30 HST dari 37.2 menjadi 35.0-35.9 SPAD (Gambar 4). Pada umur 40 HST, IKD tanaman kacang hijau pada semua perlakuan meningkat pesat menjadi 40.551.9 SPAD, dan tertinggi pada perlakuan tanpa genangan. Artinya daun sangat hijau dan tidak mengalami klorosis. Hal ini mengindikasikan bahwa tanaman sudah mengalami pemulihan setelah digenangi selama 2-6 hari mulai umur 20 HST. Indeks klorofil daun pada perlakuan kontrol lebih tinggi dibandingkan dengan perlakuan genangan. Hal ini serupa dengan hasil penelitian Islam et al. (2014) bahwa IKD pada perlakuan kontrol lebih tinggi dibandingkan dengan tanaman yang digenangi.

\section{Hasil dan Komponen Hasil}

Interaksi antara varietas dengan lama genangan tidak berpengaruh nyata terhadap peubah hasil dan komponen

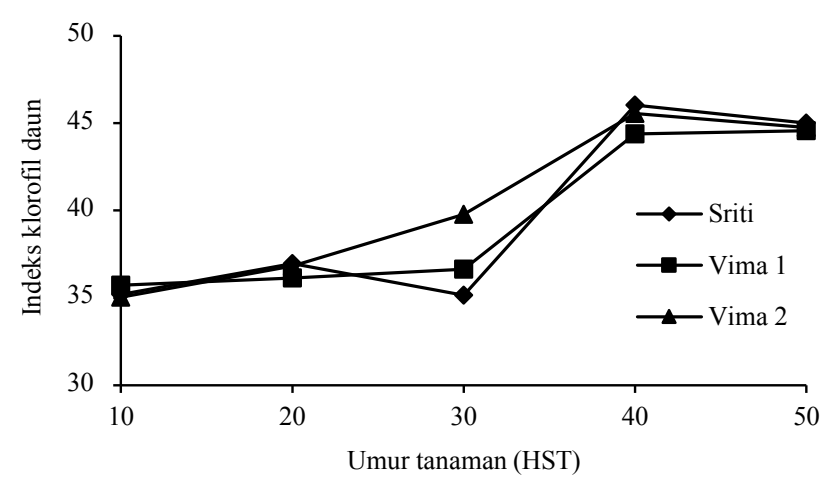

Gambar 3. Indeks klorofil daun (IKD) kacang hijau varietas Sriti, Vima 1, dan Vima 2 selama fase pertumbuhan hasil. Perbedaan jumlah polong isi dan jumlah biji disebabkan oleh perbedaan varietas dan lama genangan secara terpisah (Tabel 3). Jumlah polong isi dan jumlah biji kacang hijau yang dihasilkan pada perlakuan genangan lebih banyak apabila dibandingkan dengan perlakuan tanpa genangan (kontrol). Perlakuan genangan selama 2 hari mampu menghasilkan jumlah biji yang lebih banyak dari perlakuan tanpa genangan dan tidak berbeda nyata dengan genangan selama 4 dan 6 hari. Sementara itu, varietas Vima 2 mampu menghasilkan jumlah polong dan biji yang lebih banyak dibandingkan varietas Sriti maupun Vima 1, meskipun secara statistik tidak menunjukkan perbedaan yang nyata.

Perbedaan komponen hasil tersebut tidak menyebabkan perbedaan hasil atau bobot biji per tanaman. Hasil (bobot biji per tanaman) kacang hijau yang didapatkan oleh varietas Sriti, Vima 1,dan Vima 2 masing-masing sebesar $6.8,6.3$, dan 7.7 g. Hasil ini sejalan dengan informasi yang tertuang dalam deskripsi varietas kacang hijau yang dirilis Balitkabi (2016), rata-rata hasil varietas Sriti, Vima 1, dan Vima 2 masing-masing sebesar 1.6, 1.4, dan 1.8 ton ha ${ }^{-1}$.

Perlakuan lama genangan nyata meningkatkan jumlah polong isi dan jumlah biji. Genangan selama 4 hari mulai umur 20 HST meningkatkan jumlah polong isi dari 10 polong isi per tanaman menjadi 13 polong isi per tanaman. Genangan selama 2-6 hari meningkatkan jumlah biji per tanaman dari 87 biji per tanaman menjadi 110-125 biji/ tanaman (meningkat 26-44\%). Adanya peningkatan jumlah biji akibat perlakuan genangan tersebut tidak membuat bobot biji per tanaman berbeda nyata, walaupun nilai korelasinya sangat erat (Tabel 4). Menurut Pociecha et al. (2008); Celik dan Turhan (2011); dan Amin et al. (2017) genangan menyebabkan beberapa gangguan fisiologis, antara lain penurunan pertumbuhan, bahan kering, IKD, dan jumlah polong yang dapat menurunkan hasil kacang faba (Vicia faba L. minor), buncis, dan kacang hijau. Hasil pada penelitian ini berkebalikan dengan beberapa hasil penelitian sebelumnya dimana bobot biji pada perlakuan genangan 2 hingga 6 hari justru lebih tinggi dibandingkan dengan perlakuan tanpa genangan, hal tersebut kemungkinan disebabkan oleh perbedaan toleransi dari varietas kacang hijau yang digunakan terhadap cekaman genangan, jenis tanah yang digunakan berbeda, dan penggunaan polibag + ember yang membuat hara dalam tanah tidak banyak

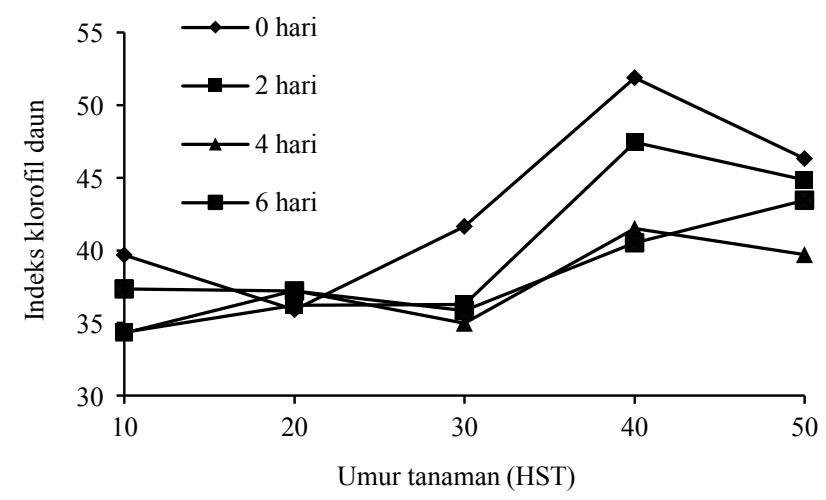

Gáııuaı 4. Indeks klorofil daun (IKD) kacang hijau pada perlakuan lama genangan selama fase pertumbuhan 
terbawa air, sehingga hasilnya menjadi lebih baik ketika mendapatkan cekaman genangan.

Jumlah polong isi berkorelasi erat dengan tinggi tanaman $(r=0.51)$, artinya peningkatan tinggi tanaman berhubungan erat dengan peningkatan jumlah polong isi. Jumlah biji berkorelasi erat dengan jumlah polong isi. Bobot biji berkorelasi erat dengan jumlah polong isi dan jumlah biji (Tabel 4). Hal tersebut menandakan bahwa peningkatan jumlah polong isi berhubungan erat dengan jumlah biji dan pada akhirnya akan meningkatkan bobot biji kacang hijau. Nilai indeks klorofil daun berkorelasi erat dengan jumlah polong isi dan jumlah biji, namun nilainya negatif. Hal ini menandakan jika nilai IKD tinggi, maka akan terjadi penurunan jumlah polong isi dan jumlah biji.

Tabel 3. Jumlah polong isi, jumlah biji, dan bobot biji kacang hijau saat panen

\begin{tabular}{cccc}
\hline Perlakuan & $\begin{array}{c}\text { Jumlah polong isi } \\
\text { per tanaman }\end{array}$ & $\begin{array}{c}\text { Jumlah biji } \\
\text { per tanaman }\end{array}$ & $\begin{array}{c}\text { Bobot biji } \\
\text { per tanaman }(\mathrm{g})\end{array}$ \\
\hline Varietas & $11 \mathrm{~b}$ & & $6.8 \mathrm{a}$ \\
Sriti & $10 \mathrm{~b}$ & $99 \mathrm{~b}$ & $6.3 \mathrm{a}$ \\
Vima 1 & $14 \mathrm{a}$ & $99 \mathrm{~b}$ & $7.7 \mathrm{a}$ \\
Vima 2 & & $131 \mathrm{a}$ & $6.2 \mathrm{a}$ \\
Lama genangan & $10 \mathrm{~b}$ & & $7.7 \mathrm{a}$ \\
0 hari & $12 \mathrm{ab}$ & $87 \mathrm{~b}$ & $7.4 \mathrm{a}$ \\
2 hari & $13 \mathrm{a}$ & $116 \mathrm{a}$ & $6.5 \mathrm{a}$ \\
4 hari & $10 \mathrm{~b}$ & $125 \mathrm{a}$ & 6.9 \\
6 hari & 11.7 & $110 \mathrm{a}$ & tn \\
\hline Rata-rata & tn & 109.7 & tn \\
Interaksi & & & \\
\hline
\end{tabular}

Keterangan: Angka yang diikuti oleh huruf yang berbeda pada kolom yang sama untuk faktor perlakuan yang sama menunjukkan perbedaan yang nyata menurut uji BNT pada $\alpha=5 \%$; tnm = tanaman

Tabel 4. Korelasi antar peubah tinggi tanaman, indeks klorofil daun, komponen hasil, dan hasil kacang hijau

\begin{tabular}{llllll}
\hline Peubah & TT & IKD & JPI & JBJ \\
\hline JPI & $0.5^{*}$ & $-0.6^{*}$ & & \\
JBJ & $0.5^{*}$ & $-0.5^{*}$ & $0.8^{*}$ & $0.7^{*}$ & $0.9^{*}$ \\
BBJ & $0.6^{*}$ & -0.3 & & \\
\hline
\end{tabular}

Keterangan: $\mathrm{TT}=$ tinggi tanaman saat panen, $\mathrm{IKD}=$ indeks klorofil daun saat panen, $\mathrm{JPI}=$ jumlah polong isi, JBJ $=$ jumlah biji, $\mathrm{BBJ}=$ bobot biji; tanda “*” berarti nyata pada taraf $5 \%$

\section{KESIMPULAN}

Perlakuan genangan berpengaruh negatif terhadap pertumbuhan tiga varietas kacang hijau, yaitu Sriti, Vima 1, dan Vima 2, yang ditunjukkan dengan pengurangan bobot kering batang dan bobot kering daun tanaman kacang hijau. Varietas Sriti tergolong toleran terhadap genangan karena mampu memulihkan pertumbuhannya dengan membentuk akar adventif lebih banyak, sedangkan Vima 1 agak toleran dan Vima 2 tidak toleran.

\section{UCAPAN TERIMA KASIH}

Terima kasih disampaikan kepada Pak Rofi'i atas bantuan dan jerih payahnya dalam membantu pelaksanaan penelitian.

\section{DAFTAR PUSTAKA}

Alamgir, H., S.N. Uddin. 2011. Mechanisms of waterlogging tolerance in wheat: Morphological and metabolic adaptations under hypoxia or anoxia. Australian J. Crop Sci. 5:1094-1110.

Amin, M.R., M.A. Karim, Q.A. Khaliq, M.R. Islam, S. Aktar. 2017. The influence of waterlogging period on yield and yield components of mungbean (Vigna radiata L. Wilczek). The Agriculturists 15:88-100.

[Balitbangtan] Badan Penelitian dan Pengembangan Pertanian. 2011. Pedoman Umum: Adaptasi Perubahan Iklim Sektor Pertanian. Kementerian Pertanian, Jakarta, ID. 
[Balitkabi] Balai Penelitian Tanaman Aneka Kacang dan Umbi. 2016. Deskripsi Varietas Unggul Aneka Kacang dan Umbi. Balai Penelitian Tanaman Aneka Kacang dan Umbi. Badan Penelitian dan Pengembangan Pertanian, Malang.

Celik, G., E. Turhan. 2011. Genotypic variation in growth and physiological responses of common bean (Phaseolus vulgaris L.) seedlings to flooding. Afr. J. Biotechnol. 10:7372-7380.

Colmer, T.D., L.A.C. Voesenek. 2009. Flooding tolerance: suites of plant traits in variable environments. Funct. Plant Biol. 36:665-681.

Du, K., L. Xu, H. Wu, B. Tu, B.Zheng. 2012. Ecophysiological and morphological adaption to soil flooding of two poplar clones differing in flood tolerance. FloraMorphology, Distribution, Functional Ecology of Plants 207:96-106.

Insausti, P., A.A. Grimoldi, E.J. Chaneton, V. Vasellati. 2001. Flooding induces a suite of adaptive plastic responses in the grass Paspalum dilatatum. New Phytol. 152:291-299.

Islam, M.R., A. Hamid, Q.A. Khaliq, J.U. Ahmed, M.M. Haque, M.A. Karim. 2007. Genetic variability in flooding tolerance of mungbean (Vigna radiata $\mathrm{L}$. Wilczek) genotypes. Euphtyica 156:247-255.

Islam, M.R., A. Hamid, Q.A. Khaliq, M.M. Haque, J.U. Ahmed, M.A. Karim. 2010. Effects of soil flooding on roots, photosynthesis, and water relations in mungbean (Vigna radiata (L.) Wilczek). Bangladesh J. Bot. 39:241-243.

Islam, M.R., N. Akter, S.M.S. Parvej, K.M.S. Haque. 2014. Growth and yield response of mungbean (Vigna radiata L. Wilczek) genotypes to wet puddling, flooding, and saturated soil cultured. Journal of Plant Science 2:311-316.

Kumar, P., M. Pal, R. Joshi, R.K. Sairam. 2013. Yield, growth, and physiological responses of mungbean [Vigna radiate (L.) Wilczek] genotypes to waterlogging at vegetative stage. Physiol. Mol. Biol. Plants 19:209220

Mimi, A. 2015. Legumes: a study of waterlogging tolerance in Gazipur, Bangladesh. Indian Res. J. Ext. Edu 15:243-257.
Munarso, P.Y. 2011. Keragaan padi hibrida pada sistem pengairan intermittent dan tergenang. Penelitian Pertanian Tanaman Pangan 30:189-195.

Pociecha, E., J. Koscielniak, W. Filek. 2008. Effect of root flooding and stage of development on the growth and photosynthesis of field bean (Vicia faba L. minor). Acta Physiol. Plant 30:529-535.

Rohmah, E.A., T.B. Saputro. 2016. Analisis pertumbuhan tanaman kedelai (Glycine max L.) varietas Grobogan pada kondisi cekaman genangan. Jurnal Sains dan Seni ITS. 5:E-29-E-33.

Safrizal, E. Santosa, Bakhtiar. 2008. Pengaruh penggenangan terhadap pertumbuhan vegetatif cabai. J. Floratek. 3:61-67.

Singh, D.P., B.B. Singh. 2011. Breeding for tolerance to abiotic stresses in mungbean. J. Food Legumes. 24:83-90.

Somavilla, N.S., D.G. Riberio. 2012. Ontogeny and characterization of aerenchymatous tissues of melastomataceae in the flooded and well-drained soils of a neotropical savanna. Flora-Morphology, Distribution, Functional Ecology of Plants. 207:212222.

Striker, G.G., P. Insausti, A.A. Grimoldi, E.L. Ploschuk, V. Vasellati. 2005. Physiological and anatomical basis of differential tolerance to soil flooding of Lotus cornciculatus L. and Lotus glaber Mill. Plant Soil 276:301-311.

Susilawati, R. A. Suwignyo, Munandar, M. Hasmeda. 2012. Karakter agronomi dan fisiologi varietas cabai merah pada kondisi cekaman genangan. J. Agron. Indonesia 40:196-203.

Trustinah, B.S. Radjit, N. Prasetiaswati, D. Harnowo. 2014. Adopsi varietas unggul kacang hijau di sentra produksi. Iptek Tanaman Pangan 9:24-38.

Ullah, Md J. 2006. Effect of waterlogging on growth and yield of mungbean cv. Kanti (Vigna radiata). Legume Res. 29:196-200. 